\title{
Effective Measures for Computer Major College Students' Entrepreneurship Quality
}

\author{
Zhong Wenbin $^{1}$, Zhu Wu $^{2}$, Gui Wei ${ }^{3^{*}}$ \\ ${ }^{1 .}$ School of Computing,Jiangxi University of Traditional Chinese Medicine, 818 Meiling Road, \\ Nanchang 330004, Jiangxi, P.R. China ; \\ 2.School of Computing,Jiangxi University of Traditional Chinese Medicine, 818 Meiling Road, \\ Nanchang 330004, Jiangxi, P.R. China ; \\ ${ }^{3}$ School of Humanities, Jiangxi University of Traditional Chinese Medicine, 818 Meiling Road, \\ Nanchang 330004, Jiangxi, P.R. China ;
}

*Corresponding author: Gui Wei .Email:178369210@qq.com

Keywords: College students; Computer major; Entrepreneurship; Improvement; Countermeasures

\begin{abstract}
After the 17th CPC National Congress was convened, the State Council attaches great importance to college students' entrepreneurial problem, because college students' entrepreneurship, especially computer major college students' entrepreneurship, can not only solve the problem of their employment, but also plays an important role in our country's economic development. To encourage college students' self-employment, entrepreneurship education is carried out for computer major students and a series of good policies for the development of new and high technology enterprises are introduced. This article carries on a thorough analysis on how to improve computer major college students' entrepreneurial quality from the concept of it and proposes corresponding implementing measures [1].

Because of college expansion, university graduates are increasing, which makes college students' employment problem more serious. And in Internet age and information age, computer major students are strong backbones who have unique business advantage. The improvement of computer major students' entrepreneurship has a profound influence on college students' employment pressure in our country. Colleges and universities should also fuse college students' entrepreneurship quality education into the process of professional education and talent training. Introduce more entrepreneurial type faculty, enrich entrepreneurship practice activities, or adopt university-enterprise cooperation to enhance students' practice ability and entrepreneurial ability and better realize college students' self-employment documents issued by the State Council and help to solve the problem of university students' employment.
\end{abstract}

\section{The basic qualities and abilities computer major students should have for entrepreneurship}

The qualities computer major students should have before innovate undertaking.

Entrepreneurship is a new choice of computer major college students' employment. It has big tests on entrepreneurs. These tests are mainly to manifest the entrepreneur's wisdom and courage, ability and spirit. Entrepreneurs must possess the basic qualities for entrepreneurial success. Entrepreneurial quality is a complex system and the formation and development of it is under the influence of education environment. It consists four parts: entrepreneurial awareness, psychological quality, entrepreneurship knowledge and competitive consciousness [2].

1).Entrepreneurial awareness. Entrepreneurial awareness refers to the entrepreneur's entrepreneurial motivation tendency, including entrepreneurs demand, motivation, psychological ideas, world outlook, values, and performs in all social nature of entrepreneurial quality, determines the attitude and behavior of entrepreneurs in entrepreneurial activity, and occupies an important position in entrepreneurial qualities. 
2). Psychological quality. Entrepreneurship is a way full of hardships and frustrations. Thus, this requires good entrepreneurial psychological quality, strong psychological ability and good adjusting and control ability. Entrepreneurial psychological quality is composed of six kinds of psychological qualities: independence, restraint, tenacity, dare, adaptability and practicability. The core of the six kinds of psychological qualities is will characteristics and emotional characteristics. In other words, entrepreneur will and emotion are reflected from a certain angle. So, to seize the overall characteristics of entrepreneurship psychological quality, there are two elements, consciousness and emotion, need to be seized.

3). Entrepreneurship knowledge. The difficult coefficient of entrepreneurship requires entrepreneurs themselves have rich cultural knowledge. The cultural knowledge here not only refers to professional theory knowledge, but also includes the comprehensive knowledge of enterprise management and professional ethics knowledge and related laws and regulations and so on. In terms of the composition subsystem of entrepreneur knowledge, professional theoretical knowledge is the foundation for entrepreneurship laid by entrepreneurs. Professional theory knowledge degree determines the starting point of entrepreneurship. And management knowledge, comprehensive knowledge, modern enterprise management ability and comprehensive ability are high-level, high value knowledge, which have good internal resources setting and social management strategies so they play the same role in enterprise management [3].

4). Competitive consciousness. The most obvious and fierce feature in market economy is full of competition, and at the same time, competition also is fundamental to business survival and sustainable development and indispensable spirit for market economy. For enterprises, competition is to improve. To succeed, entrepreneurs must have competition consciousness in the entrepreneurship way, and put competition consciousness into practice and then they can succeed.

\section{The abilities computer major students should have for entrepreneurship.}

1). Have solid professional knowledge and construction ability. To realize the idea of selfemployment, computer major students not only have to learn cultural knowledge such as mathematics, English and physics, but learn professional courses like programming language, network technology, software engineering and information systems. The knowledge is the foundation and condition of college students' entrepreneurship, and they are computer major students' knowledge source to play their potential to the full. In addition, college students must have certain construction ability, and build knowledge acquisition ability, expression ability, and good knowledge usability. Master system details and clearly recognize all the system. They can not only master professional theory knowledge, but also are good at using the theory to instruct practice.

2). Better comprehensive quality and ability. Cultivating high-quality talents in colleges and universities not only just give professional knowledge education, but pay more attention to comprehensive quality education for college students. Comprehensive qualities include ideological and moral cultivation quality, cultural quality, professional quality and physical and psychological quality, etc. Quality of ideological and moral cultivation has important effect on college students in forming correct world outlook, values, outlook on life and improves their social responsibility, especially for college students of computer science. Individual ideology and morality influence their development. In addition, college students must value and strengthen their physical and mental quality education to adapt to the fierce competition on the way of entrepreneurship. Learn communication skills with others, strengthen competition and make sufficient preparation for selfemployment.

3). Have innovation ability. Entrepreneurship is to innovate based on employment, and innovation ability is an ability computer major college students with self-employed consciousness need. Entrepreneurs should correctly view other people's business story, rather than blindly imitate or copy. In addition, clearly realize that no one can succeed once. For any successful entrepreneur, success always builds on failure. A successful essential quality for successful entrepreneurs is to know how to fuse others entrepreneurial experience into their entrepreneurial awareness. Only in this way, entrepreneurs can calmly face and solve the problems in failures and difficulties. 
4). Enterprise management ability. Enterprise management ability refers to the management of enterprise employees and capital ability after entrepreneurs succeed in the business because it is directly related to the sustainable development and survival of the enterprise future [4]. Computer major students with self-employment idea should not only have certain knowledge of market, market research and analysis ability, but also know enterprise marketing strategy in the market and be proficient in business accounting work, etc.

\section{The problems in computer major college students in the course of entrepreneurship}

\section{Entrepreneurship form is not practical.}

First, entrepreneurs lack confidence and rely too much on the leader.Computer is a multidisciplinary major, so when entrepreneurs think the leader's professional ability is better than them when they see the leader easily solves their own weaknesses, which leads to completely obey the leader's views on project analysis and ignore their opinions; second, entrepreneurs lack entrepreneurship preparation and overestimate their comprehensive ability. Entrepreneurs have hot brain. Form a team in the absence of preparation. After business failure, contradiction appears on the team thought and eventually it dissolved; Third, professional ability. Computer is a complex, logical thinking, strong professional discipline. Entrepreneurs' professional ability is related to the team's overall ability; therefore, entrepreneurs and cooperation must have autonomous learning ability.

\section{Relatively weak entrepreneur market awareness.}

Computer major college students' thinking is very careful and stronger new things acceptance ability. Self-employment consciousness is very strong, but computer major students are a bit poor in interpersonal communication, coordination and organization management performance. One of the biggest problems is that they lack market awareness and they are willing to talk about their own unique technologies and products with investors but neglect to introduce investors product market space; Lack market positioning, which leads to products are in the stage of business needs rather than directly sign a permanent supply with market and the merchant [5].

There is a gap between skill levels and entrepreneurship requirements.

The training of colleges and universities computer specialists is carried out according to talent training teaching system and syllabus, and students finish their studies in accordance with the requirements. However, computer major is a strong practical and thoughtful major. In computer education in colleges and universities, heavy theory and light practice is very common, which leads to the theory knowledge computer major students learned can't keep up with the pace of business. In addition, students' practice during the school period is not in the same enterprise, so it is hard to get work experience, enterprise benefit consciousness, market economy and so on. Therefore, college students lack competitiveness in entrepreneurship.

\section{Measures to improve computer major college students' entrepreneurial quality}

\section{Computer major students should have a strong sense of self-employment consciousness.}

First, computer major university students should set up self-employment consciousness and change the old ideas of employment. Use their learned professional knowledge and technology, seek business partners by raising venture capital or technology investment, and create their own business and provide more employment opportunities for the society. Second, give full play to their innovative ability while mastering computer professional theory knowledge and do not be limited to business practice. Participate in entrepreneur contest or business project development activities organized by the society or school as much as possible. Third, apply self-employment consciousness into practice. Have self-employment consciousness and business knowledge is not enough, what is more important is to apply their talents to entrepreneurial practice. 


\section{University should advocate and develop computer major college students' entrepreneurial quality.}

Colleges and universities can give market economic research guidance combining teaching material to students. In corporate entrepreneurship skills teaching for students, try to leave classroom teaching and move to certain enterprise or inside practice base, because classroom environment is very different from actual work environment. School and enterprise may carry out interactive platform to let the students gain a better understanding of market economy and modern enterprise management, accumulate work experience and improve their operation ability. Enterprise managements or business elites are hired to school, or let the students practice in the enterprise. Let students understand the professional employment environment in advance and lay a good foundation for later self-employment [6]; Use night lessons to organize more computer major students to interview entrepreneurs and other activities; Strengthen laboratory construction and curriculum design, strengthen professional teaching skills training, and timely organize students to conduct entrepreneurship design competition. Let the students give full play to their imagination and participate in business competition as entrepreneurs.

\section{Government should vigorously support and advocate computer major college students' self-employment.}

To implement the entrepreneurship policy issued by State Council aiming at computer major college students, in the process of cultivating college students' entrepreneurship ability, government should appropriately give college students entrepreneurship policy tilt, and optimize entrepreneurial environment for college students. If allowed, government can establish "college students' venture incubation practice base", aiming at developing new market competition rules for college students entrepreneurship; College students are bound to bear the pressure of financing at the beginning, therefore, government can also take three effective channels, social, Banks and government, to set up "Special fund for carving" and "College students entrepreneurship loan" to help college students solve the problem of financing and ease the pressure on college students' financing burden.

\section{Conclusion}

The continued growth of our country's economy, to a certain extent, promotes the development of small and medium-sized enterprises and partially solves the problem of university students' employment. However, with the continuous expansion of universities, college graduate employment difficulty is more and more serious. For this, based on network era, State Council put forward selfemployment suggestion to university computer major college students, hoping that computer professional college students can be self-employed after graduation and they can provide employment opportunities for themselves and the society.

\section{References}

[1] Li Ying. College computer major students' innovative entrepreneurial ability exploration and practice [J]. Journal of Electronic Test, 2016 (5): 134-135.

[2] Liu Jun. Computer major college students' entrepreneurship professional ability status and promotion path [J]. Journal of Xiamen City Vocational College, 2016 (3): 72-77.

[3] Xu Xiuhui. Computer major college students' entrepreneurial ability promotion path research [J]. Journal of Hubei Institute of Technology, 2016 (1): 175-177.

[4] Yao Xiaoyi. Improve the entrepreneurial ability of computer major students [J]. Journal of Information and Computer: Theory, 2015 (2).

[5] Li Hua, Zhou Shiyou, Wang Jin. Higher vocational computer major students' entrepreneurship education research under the background "three simultaneous" [J]. Science and Technology, 2015 (2). 
[6] Liang Junjie. Colleges and universities computer software major students' entrepreneurship ability training [J]. Science Tribune, 2012 (1): 156-157. 